\title{
Cast of characters, names and places
}

\begin{tabular}{|c|c|}
\hline John & Owner-manager, Fenderco \\
\hline Paul & Owner-manager, Fenderco \\
\hline Will & Assistant, Fenderco \\
\hline Mark & Assistant, Fenderco \\
\hline Fenderco & Paul and John's joint venture company \\
\hline FendercoEurope & Fenderco's European partner in the joint venture \\
\hline Jurgen & Managing Director of FendercoEurope \\
\hline Ausfend & Fenderco's Australian corporate partner in joint venture \\
\hline Harbourco & $\begin{array}{l}\text { Paul and John's employer prior to buyout from } \\
\text { EuroPort }\end{array}$ \\
\hline EuroPort & $\begin{array}{l}\text { Corporate buyers of Harbourco: last employers of Paul } \\
\text { and John before starting Fenderco }\end{array}$ \\
\hline Steel Applications & One of Paul and John's other related companies \\
\hline The 'castle house' & Paul's home \\
\hline The Grinning Cat & Local pub \\
\hline Maltonbury & Middle-England town where Fenderco is based \\
\hline
\end{tabular}

